\title{
AGILE SUPPLY CHAIN: STRATEGY FOR COMPETITIVE ADVANTAGE
}

\author{
Intaher Marcus AMBE \\ University of South Africa
}

\begin{abstract}
The main objective of this paper is to explore the concept of agile supply chain and to determine the link between agile supply chain and competitive advantage. The $21^{\text {st }}$ century has led to increase in global competition and customer demands, with higher levels of turbulence and volatility in the market place. Businesses, economics and political environments are increasingly subjected to unexpected shocks and discontinuities. As a result of these uncertainties, organisations today are faced with a number of challenges in the supply chain which include among others the ability to meet up with changes in demand variability, service improvements, lowering inbound costs, improving ontime delivery and shorter customer lead times. In order to survive, companies need to respond to ever-increasing levels of volatility in demand and focus their efforts upon achieving greater agility. Agility has the ability to rapidly respond to changes in market and customer demands as the bearer of competitive advantage. Therefore, companies need to re-design their supply chain to tackle issues of agility in order to stay ahead in a highly competitive global market.
\end{abstract}

Key Words: Agility; Competitive Advantage; Strategy; Supply Chain Management.

\section{INTRODUCTION}

The turbulent market conditions in the 21st century have heightened the need for more competitive strategies to be developed for growth (Sanchez and Perez, 2007:681). Business, economics and the political environments are increasingly subjected to unexpected shocks and discontinuities. Many strategic issues that confront business today stem from: the new rules of competition, globalisation down pressure on price and the customer taking control. Also, as a result of the recent economic meltdown, companies around the world are confronted by a perfect storm: frozen credit market and long global recession. Events are moving so rapidly that it is almost impossible to access the implication of the meltdown for the days ahead, let alone the years to come (Njoroge, 2009:2).

The world is in the era of supply chain competition, where organisation no longer acts in isolation as an independent entity, but as a supply chain to create value delivery systems that are more responsive to fast-changing markets, more consistent and reliable (Christopher, 2005:29: Pandey and Gaug, 2009:99). The core capabilities of a company lie in its ability to design and manage its supply chain in order to gain maximum advantage in the market where competitive forces are changing. New managerial practices and unique business models emerge and fade constantly as managers strive to help their companies succeed in this less-kind, less gentle and less predictable world (Fawcett, Ellram and Ogden, 2007). The best word to describe the global market today is volatility. Organisations have to develop strategies in order to respond to ever-increasing levels of volatility in demand (Vinodh, Sundaraj and Devadasan, 2009:570). The big question is: How are supply chain executives coping with the changing business environment and what strategy can be implemented to achieve competitive advantage in their supply chain? Agility has the ability to rapidly respond to changes in market and customer demands as the bearer of competitive advantage. Despite the obvious benefits of agility, organisations are faced with challenges in implementing the measures necessary to increase their agility (Ismail and Sharifi, 2006:431). The paper explores the concept of agile supply chain and competitive advantage and presents a framework on the linkage between agile supply chain and competitive advantage. The remaining sections of the paper presents supply chain management, supply chain strategies, competitive advantage in the supply chain, framework for aligning supply chain and competitive strategies and conclusion. 


\section{SUPPLY CHAIN MANAGEMENT}

Supply chain management can be defined as "the design and management of seamless, value-added process across organisational boundaries to meet the real needs of the end customer" (Fawcett et al., (2007:8). As noted by Gansler, Luby and Kornberg (2004: 8), SCM is the management and control of all materials, funds and related information in the logistics process from the acquisition of raw materials to the delivery of finished products to the end user. More so, Hugo et.al (2004:5) defines "SCM as the management philosophy aimed at integrating a network of upstream linkages (sources of supply), internal linkages inside the organization and downstream linkages (distribution and ulti-mate customer) in performing specific processes and activities that will ultimately create and opti-mize value for the customer in the form of products and services which are specifically aimed at satisfying customer demands". Generally, SCM involves relationships and managing the inflow and outflow of goods, services and information (network) between and within producers, manufacturers and the consumers (Samaranayake, 2005:48).

Although the definitions of SCM differ across authors, it exists in all organisational types and can be classified into three categories: a management philosophy, implementation of a management phi-losophy and as a set of management processes (Klemencic, 2006:13; Lambert, 2006:13). Successful SCM requires a change from managing individual functions to integrating activities into SCM processes. The SCM processes identified by members of The Global Supply Chain Forum are (Lambert, 2006:13): customer relation management; customer service management; demand management; order fulfilment; manufacturing flow management; supplier relationship management; product development and customici-alisation; and returns management.

A supply chain includes all activities, functions and facilities (directly or indirectly) in the flow and transformation of goods and services from the material stage to the end user (Sherer, 2005:79). It is conceptualised as a network of companies from suppliers to end-users, with the intention of integrating supply and demand through coordinated company efforts. A supply chain links organisations in the upstream as well as the downstream flows of materials and information (Monczka Trent and Handfield, 2005:9). It comprises of a physical element and an information element. It is viewed as the formation of a value chain network consisting of individual functional entities committed to the controlled sharing of business data and processes. It consists of an upstream supplier network and downstream channel (Klemencic, 2006:7).Today; many organisations have become part of at least one supply chain. They have to perform equally well in order to achieve better performance.

The objective of SCM is to maximise value in the supply chain. The value a supply chain generates is the differences between what the final product is worth to the customer and cost the supply chain will in-cure to fulfil the customers' request (Chopra and Meindl, 2010:22). SCM is about competing on value, collaborating with customers and suppliers to create a position of strength in the market-place based on value derived from end consumer (Chopra and Meindl, 2007:23). Within an organisa-tion, customer value is created through collaboration and cooperation to improve efficiency (lower cost) or market effectiveness (added benefits) in ways that are most valuable to key customers. Value is not inherent in products or services, but rather is perceived or experienced by the customer (Handfield, Monczka, Giunipero and Petterson, 2009:11). The ultimate goal of a SCM process is to create customer and shareholder value, thus often called a value delivery system.

SCM encompasses planning, manufacturing and operations management necessary to bring a product to the market place, from the sourcing of materials to the delivery of the completed product. Some of the issues to consider when developing or managing a supply chain include integration, information technology, collaboration, customer and supplier relationships, partnerships, outsourcing and global issues as well as social and environmental issues (Borade and Nansod, 2007:112).

\section{SUPPLY CHAIN STRATEGIES}

A supply chain strategy is defined, relative to its competitors', the set of customer needs that it seeks to satisfy through its products and services (Chopra and Meindl, 2007: 22). Strategy involves deci- 
sions relating to the selection of suppliers, the location of facilities and the choice of distribution channels. These decisions are all driven by the goal of enabling the marketing objectives of the organisation to be achieved. A typical supply chain strategy should be aimed at achieving a smooth flow at minimum cost. It is now increasingly accepted that "one size does not fit all" when it comes to designing a supply chain strategy to support a wide range of products with different characteristics sold in a diversity of markets (Christopher, Peck and Towill, 2006:277). Supply chain strategies should be tailored to match the required 'order winning criteria' in the market place. Aligning the firm's operations with market place requirements has not always been extended to the wider supply chain. An organisation's sourcing strategy, operations strategy and route-to-market needs to be appropriate to specific product/market condition (Christopher 2005:117). The fundamental changes in the environment of global competition and trends such as outsourcing require organisations to develop supply chain strategies that are aligned to "appropriate value propositions" and customer market segments. The major generic strategies in supply chain are lean and agility. Leanness means developing a value stream to eliminate all waste including time, and to enable a level schedule where as Agility means using market knowledge and a virtual corporation to exploit profitable opportunities in a volatile marketplace (Mason-Jones, Naylor and Towill, 2000:4064). The concepts of leanness and agility, within the content of SCM have attracted the interest of many authors such as Christopher (2005); Simons and Zokaei (2005); Taj and Berro (2006); Ismail and Sharifi (2006); Gurumurthy and Kodali (2009).

\section{Lean vs Agile Supply Chain Strategies}

The concept of agile supply chains was introduced to transfer and apply the winning strategy of agility to that of supply chains (Harrison et al., 1999). It is a newly accepted unit of business. Agility in the context of supply chain management focuses on "responsiveness" (Lee and Lau, 1999; Christopher and Towill, 2000). Existing literature on agility presents it as a general concept, often linked to manufacturing only. A supply chain provides more practical setting for assessing agile capabilities (Van Hoek et al., 2001). It is unlikely that any single organisation will be able to produce artifacts with correctly configured customization and added value to satisfy a particular emergent market demand. Agility suggests cooperation to enhance competitiveness within organisations. Several authors claim that it is difficult to estimate agility directly in the supply chain (Christopher, 2000; Van Hoek et al., 2001). In order to reduce this significant deficiency, the supply chain is frequently introduced as an area where the agility concept can be applied in operations.

The key elements of an agile approach are very similar to the elements of the agile supply chain. Agility is all about customer responsiveness, people and information, cooperation within and between firms and fitting a company for change. To be truly agile, a supply chain must possess a number of distinguishing characteristics which include: market sensitivity, virtuality, process integration, and networking (Kisperska-Moron and Swiercze, 2008: 2). Parallel developments in the areas of agility and supply chain management led to the introduction of an agile supply chain (Harrison et al. 1999, Christopher 2000). While agility is accepted widely as a winning strategy for growth, even a basis for survival in certain business environments, the idea of creating agile supply chains has become a logical step for companies (Ismail and Sharifi 2006:434). Agility in a supply chain is the ability of the supply chain as a whole and its members to rapidly align the network and its operations to dynamic and turbulent requirements of the customers. The main focus is on running businesses in network structures with an adequate level of agility to respond to changes as well as proactively anticipate changes and seek new emerging opportunities.

With the increase in competition and companies wooing the customer, agile supply chain has emerged as the new mantra. Those who can meet customer demands are more successful. With consumer preferences changing fast it became even more important to bring in new products at a pace that would put a supersonic to shame. But doesn't this pace fly in the face of global supply chains that thrive on "best price" sourcing? To some extent yes, no longer is the customer willing to wait three months to wear her fashion (clothes) that is made and exported from a country thousands of miles away. Fashion considerations now rule the day: if the product for example a dress is to be worn, its time is now, before everyone else is wearing it. 'Lean' works best in a high volume, low variety and predictable environments, whereas 'Agility' is needed in a less predictable environment 
where the demand for variety is high. What about factories that have been specifically built to achieve economies of scale? Are they helping their cause? Every single organisation (manufacturing) that wants to maximize economies of scale will find itself struggling when that customer comes knocking to place orders and wants quick response for its products.

So when should an organisation pursue agility? Typical products that qualify for this consideration are electronics and fashion items. These products are sold for their "distinctive" appeal and not really for the function they perform. They have short life cycles and shorter shelf lives. Demand for these products is difficult to forecast and stock-out rates can be astronomic. In some situation, there may exist, the need for both lean and agile supply chain solution since some products will have predictable demand whilst for others, the demand will be far more volatile. Identifying the types of supply chain strategies might be appropriate in different circumstances to position the product in an organization's portfolio according to their supply and demand characteristics. Supply characteristics include: the lead time of replenishment and it is clear that different supply chain strategy will be employed when lead times are shorter than when they are longer. With shorter lead times, there is a rush to make everything distinct in today's global marketplace, from biscuits to Barbie dolls. Commoditization is diminishing with each passing day.

Markets are reorganizing from mass markets into highly fragmented niche markets. So is lean dead? Hardly, it exists for "functional" products, those used for our basic needs (such as food). These products have predictable demand and hence are easier to forecast. The stock-out rates are negligible. The predictable demand of lean supply chain makes the tasks easier for companies as they can focus on one prime goal: Cost reduction. Sophisticated systems and processes ensure that technology plays the required role in meeting this goal. Inventory is minimized and efficiency throughout the supply chain is maximized to get the desired results. All upstream and downstream functions collaborate to make sure that the predicted demand numbers are met at the minimum cost possible. Christopher and Towill (2002:9) suggested four broad generic supply chains strategies dependent upon the combination of supply and demand conditions for each product. These demand conditions might be characterized by predictability of demand as shown in figure 1 .

Figure 1: Demand and Supply Characteristics

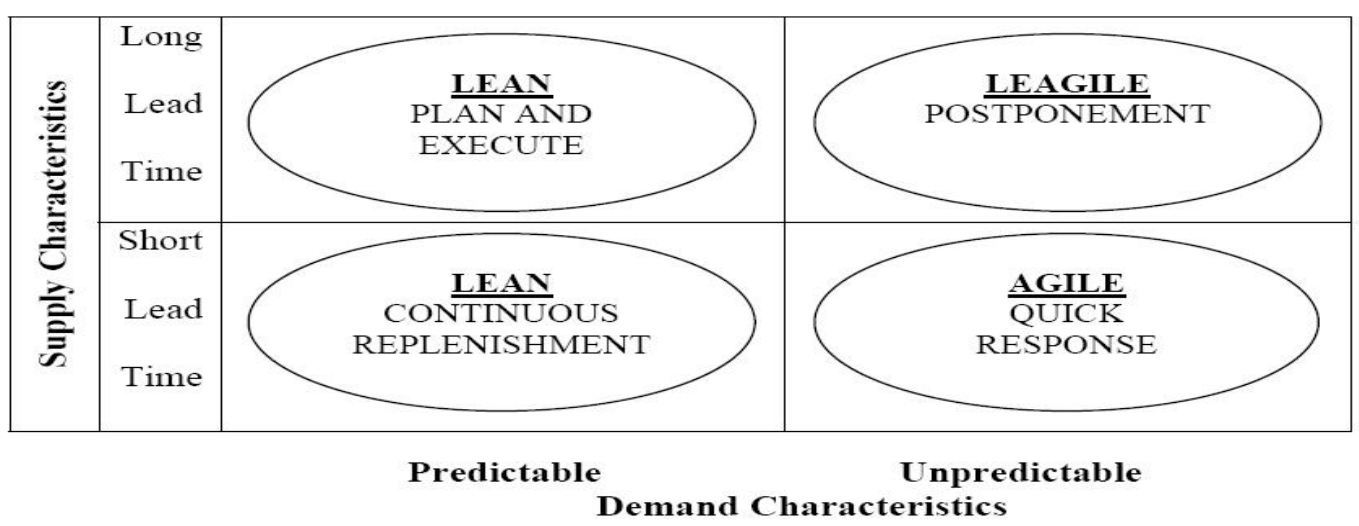

(Christopher and Towill, 2002:9)

The demand characteristics in terms of 'predictability' determine the variability of demand. Selecting a strategic approach (lean or agile) in a supply chain can be complex. Intelligent supply chains throughout the world use a combination of lean and agile for their benefit. Table 1 shows some of the attributes that distinguishes lean and agile supply. 
Table 1: Attributes of Lean and Agile Supply

\begin{tabular}{|l|l|l|}
\hline $\begin{array}{l}\text { DISTINQUISHING } \\
\text { ATTRIBUTES }\end{array}$ & LEAN SUPPLY & AGILE SUPPLY \\
\hline Typical products & Commodities & Fashion Goods \\
\hline Marketplace Demand & Predictable & Volatile \\
\hline Product Variety & Low & High \\
\hline Product Life cycle & Long & Short \\
\hline Customer Drivers & Cost & Availability \\
\hline Profit Margin & Low & High \\
\hline Dominant Costs & Physical Costs & Marketability \\
\hline Stockout Penalties & Long term Contractual & Immediate and Volatile \\
\hline Purchasing Policy & Buy Goods & Assign Capacity \\
\hline Information Enrichment & Highly Desirable & Obligatory \\
\hline Forecasting Mechanism & Algorithms & Consultative \\
\hline
\end{tabular}

(Christopher and Towill, 2000:208)

Supply chain performance improvement initiatives should be focused on matching supply to demand thereby driving down costs simultaneously with improving customer satisfaction. This invariably requires uncertainty within the supply chain to be reduced as much as practicable so as to facilitate a more predictable upstream demand (Mason-Jones et al., 2000). Specific supply chains are faced with the situation where they have to accept uncertainty but need to develop a strategy that enables them to still match supply and demand. One way to distinguish between supply chains strategies is through the product types for which each strategy is used. Fisher, (1997), classified products into two generic types, fashion and commodities as follows:

- Fashion products: They have a short life cycle and high demand uncertainty, therefore exposing the supply chain to the risks of both stock out and obsolescence. A good example of a fashion product is trendy clothing. The challenge faced by a supply chain delivering fashion products is to develop a strategy that will improve the match between supply and demand and enable the companies to respond faster to the marketplace. Agile supply chains are typically used for fashion products.

- Commodities: These are basic products, such as tinned soups, have relatively long life cycles and have low demand uncertainty due to the fact they tend to be well-established products with a known consumption pattern. The driving force for basic product supply chains is therefore cost reduction. Lean supply chains are typically used for commodities.

When you know your supply chain strategy, it is important to determine the market Winners and market Qualifiers for its products. According to Hill (1993) there is a considerable difference between the two groups of products ('order qualifiers' and 'order winners') against which manufacturing strategies should be determined. Every business needs to understand what the baseline is for entering into the competitive arena (the order qualifiers). Order Qualifiers are those (minimum) criteria that a company must meet to be considered as a possible supplier while order winners are those criteria that win the orders. The definition of order qualifiers and order winners logically leads to the specification of the appropriate manufacturing strategy. It is on this basis that the concept of 'market qualifiers' and 'market winners' developed (Christopher and Towill, 2002). Table 2 depicts a framework for market winners and market qualifiers. 
Table 2: Market Winners and market Qualifiers

\author{
Fashion Goods \\ (Agile Characteristics)

\section{Commodities (Lean Characteristics)}

(Mason-Jones et al., 2000: 4046)

\begin{tabular}{|cl|ll|}
\hline$\bullet$ & Quality & $\bullet$ & Service Level \\
$\bullet$ & Price & \\
\hline$\bullet$ & Lead Time & Quality & Lead Time \\
$\bullet$ & Service Level & & \\
\hline
\end{tabular}

Market Qualifiers
Market Winners

The market winner for fashion products is availability, whereas the market winner for commodities is price. Quality and lead-time are market qualifiers in both cases: price and availability are market qualifiers for fashion products and commodities respectively. The emphasis on the figure is that supply chain must excel at the market winner metrics and be highly competitive at the market qualifier metrics that is the minimum standard for entry into the marketplace. These two product types respond to distinctly different marketplace pressures and hence require a different supply chain approach to address their specific characteristics. Understanding the particular characteristics of the product type, marketplace requirements and management challenges, will help an organisation to design the correct supply chain strategy that will ensure optimal performance and gain competitive advantage. This can be achieved via developing strategies that will reduce the effect of the systeminduced uncertainty, thereby reducing the Bullwhip effect and, at the same time, actively coping with the particular marketplace uncertainty pressures.

Looking at the different characteristics, there are different ways that an organisation can integrate lean and agile supply chain. Based on the attributes of lean and agile supply chain, it is evident that a number of common characteristics exist and the whole concept can co-exist. There are three ways in which Leanness and agility can sometimes be combined. That is through the strategic use the pareto curve approach, the decoupling point and the 'base and surge' demands (Christopher, 2005). Therefore, instead of a "pure" agile and pure lean supply chain, there will often be situations where a combination of the two may be appropriate, i.e. a hybrid strategy, that is, a mixed portfolio of products and markets, there will be some products, where demand is stable and predictable, and some products where the converse is true. As Fisher (1997) points out, it is important that the characteristics of demand are recognized in the design of supply chains. Also, it is not necessarily that a supply chain should be either lean or agile. Instead, a supply chain may need to be lean for part of the time and agile for the rest. Naylor, Naim and Berry (1999) and Mason-Jones et al. (2000) present the term "leagility" - the combination of the lean and agile paradigm within a total supply chain strategy positioning the decoupling point, so as to best suit the need for responding to a volatile demand downstream yet providing level scheduling upstream from the decoupling point.

\section{COMPETITIVE ADVANTAGE}

Competitive advantage exists when a firm has a product or service that is perceived by its target market customers as better than that of its competitors. It is an advantage an organisation has over competitors, gained by offering consumers greater value, either by means of lower prices or by providing greater benefits and service that justifies higher prices. SCM is about competing on value, collaborating with customers and suppliers to create a position of strength in the marketplace based on value derived from end consumer. The overall objectives of SCM is to create value for customers, competitive advantage and improved profitability for supply chain firms, the dimensions of value that may be important to customers, and the mechanisms whereby competitive advantage and improved profitability can be achieved. Within an organisation, customer value is created through collaboration and cooperation to improve efficiency (lower cost) or market effectiveness (added benefits) in ways that are most valuable to key customers. Value is not inherent in products or services, but rather is perceived or experienced by the customer. Therefore, in order to compete through creating customer value, a firm must understand, and deliver the value perceived as important by its customers. By satisfying customers and achieving competitive advantage, firms in a supply chain influence 
customers to make choices and behave in ways that improve the financial performance of the supply chain and the firms within it.

An organisation's competitive advantage is built upon a well-planned and executed supply chain management strategy that is sustainable. This is because it is broadly considered as a philosophy of management. Supply chain management is never totally attained by any company or group of companies, nor can the elements of success enjoyed by one supply network be transferred to another with the expectation of identical levels of performance. Therefore, competitive advantage belong to those supply chains that can activate concurrent business processes and core competences that merge infrastructures, share risks and costs, leverage the shortness of today's product lifecycle, reduce time to market, and gain and anticipate new vistas for competitive leadership (Ross 1998.) In the competitive context, successful companies either have a productivity advantage (or cost advantage) or value advantage, or ideally, a combination of these two (Christopher 1998, McKinnon 2001). A supply chain is a part of an organisation's competitive advantage. No producer is an island nor can any organization work independently from its supply chain. Every organization works in teams or supply chains. So if any part of the chain is weak then the whole business model becomes weak. Wastes and inefficiencies that cannot be passed on to the customer result in costs and low profits for the producer - an uncompetitive position. In basic terms, the supply chain consists of suppliers, customers and, the producer. Competitive advantage can be achieved by aligning the supply chain strategy to the competitive strategy.

\section{Competitive Strategies}

A firm's relative position within an industry is given by its choice of competitive advantage (cost leadership vs. differentiation) and its choice of competitive scope. Competitive scope distinguishes between firms targeting broad industry segments and firms focusing on a narrow segment. Generic strategies (Porter, 1995:12) are useful because they characterize strategic positions at the simplest and broadest level. Porter (1995) maintains that achieving competitive advantage requires a firm to make a choice about the type and scope of its competitive advantage. There are different risks inherent in each generic strategy, but being "all things to all people" is a sure recipe for mediocrity - getting "stuck in the middle". Therefore an organization can create competitive advantage through:

- Cost Leadership: Cost advantage occurs when an organization delivers the same services as its competitors at a lower cost.

- Differentiation: Differentiation advantage occurs when an organization delivers greater services for the same price of its competitors. They are collectively known as positional advantages because they denote the firm's position in its industry as a leader in either superior services or cost.

- Focus: A focused approach requires a fir, to concentrate on a narrow rather than industry wide competitive advantage.

\section{Table 3: Attributes of Cost Leadership and Differentiation Strategies}

\begin{tabular}{|c|c|}
\hline Cost Leadership & Differentiation \\
\hline • $\quad$ efficiency & • $\quad$ effectiveness \\
\hline - $\quad$ standardization & - $\quad$ customization \\
\hline - $\quad$ mass production & shorter production runs \\
\hline process improvement & product development \\
\hline reduced service & enhanced service \\
\hline - $\quad$ stability & flexibility \\
\hline cost accounting skill & strong marketing \\
\hline
\end{tabular}

Based on the attributes of exhibit 4, there is a linkage between agile supply chain and the competitive strategies. An agile supply chain responds rapidly to changes in the business environment; align with the firm's competitive strategy to improve competitive performance, hence gain competitive advantage. The bottom line is the cost minimisation, improved quality product/services, gain competency and increase speed. This is illustrated in figure 2 below. 
Figure 2: The Link between Agile Supply Chain and Competitive Strategies

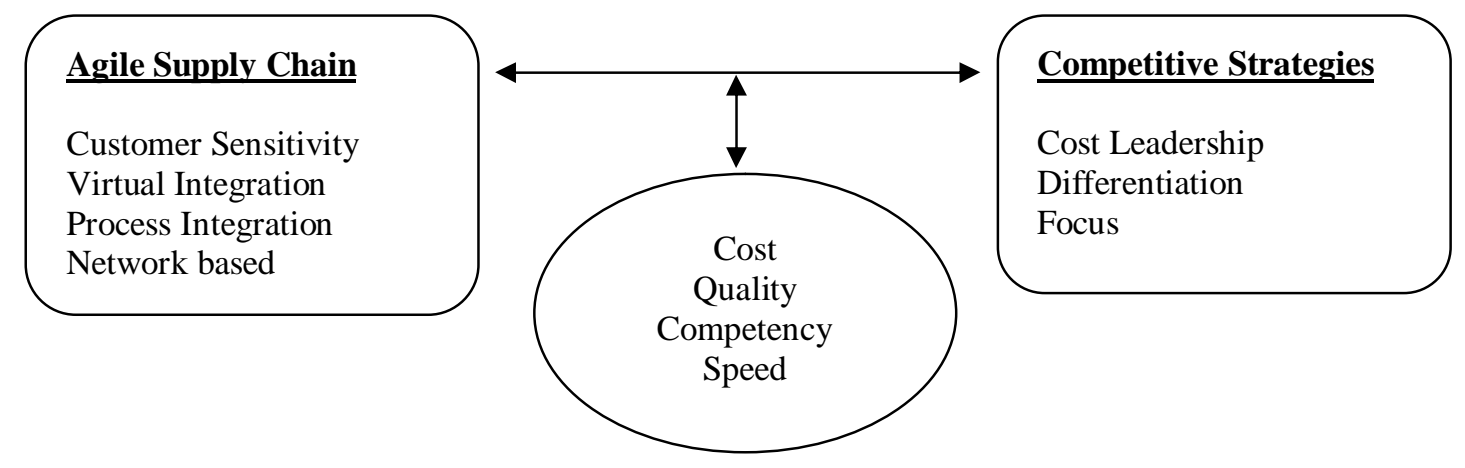

\section{FRAMEWORK FOR ALIGNING AGILE SUPPLY CHAIN TO COMPETITIVE STRATEGIES}

The aim of the proposed framework is to map the link between agile supply chain and competitive advantage. In this turbulent uncertainty in the business environment, it is important to determine your market, the nature of products and services, the market winners and market qualifiers to determine your supply chain strategy. As indicated in the paper, the best supply chain strategy to use to meet customer expectation when demand is uncertain is agile supply chain. In an uncertain business environment, competitive advantage is achieved when you determine the drivers of change, be flexible, adaptive and responsive through agile supply chain strategy; and align your supply chain strategy to the overall business strategy to gain competitive advantage as explained below.

Drivers of Change: The main driving force behind agility is change. It is changes or pressures in a business environment that force a company to search for new ways of running its business in order to maintain its competitive advantage. The change drivers can be characterized by the following elements: changes in marketplace; changes in customer requirements; changes in competition criteria; changes in technology; as well as changes in social factors (Ismail and Sharifi 2006:434). When a business venture is faced with rapid changes, agility supply chain strategy should be employed to respond quickly to counter act the effect of the changes to gain competitive advantage.

Agile Supply Chain: An agile supply chain requires various distinguishing capabilities in order to enrich and satisfy customers. These include: responsiveness, flexibility and adaptability. To be truly agile, an organisation must possess the following elements: market sensitive, process integration, network based and virtual (Christopher, 2000). They should be able to be flexible, responsive and adapt to changing market conditions. This can be achieved through collaborative relationship, process integration, information integration, and customer/marketing sensitivity achieving customersatisfied objectives. These include cost, time, competency and speed in the supply chain contributing to competitive advantage of the entire organisation.

Competitive Strategies: An organisation's position in the industry in which it operates is determined by its competitive strategy. A winning competitive strategy is founded on consistently understanding and predicting changing market conditions and customer needs. Agile supply chain must be aligned to the competitive strategies to improve the overall performance of the organisation. The target of agile supply chain is to provide personalized products with unique features to the market quickly in order to maintain a competitive advantage in today's changing environment. In order to fulfill such a target, the supply chain may maintain a substantive stock of components waiting for the final assembly or configuration. That is a converse method to the lean supply chain that is a costadvantage strategy. Goldman et al. (1995) contended that the market segmentation is a major force for introducing and implementing agility in an organization. Through the share of market knowledge and competencies of partners, the agile supply chain can make detail market segmentation and introduce new product more quickly. Porter's differentiation strategy refers to the unique image or value of products and services. In the context of supply chain management, the agile supply chain is the most appropriate format to fulfill the specific goal of Porter's differentiation strategies and is appro- 
priate to meet the challenges of the business environment. If you know your supply chain strategy and your competitive strategy, based on the product and the customers, aligning the two strategies will lead to competitive performance in the organization. Figure 3 below shows the framework for agile supply chain as a strategy for competitive advantage.

\section{Figure 3: Aligning Agile Supply Chain to Competitive Strategies}

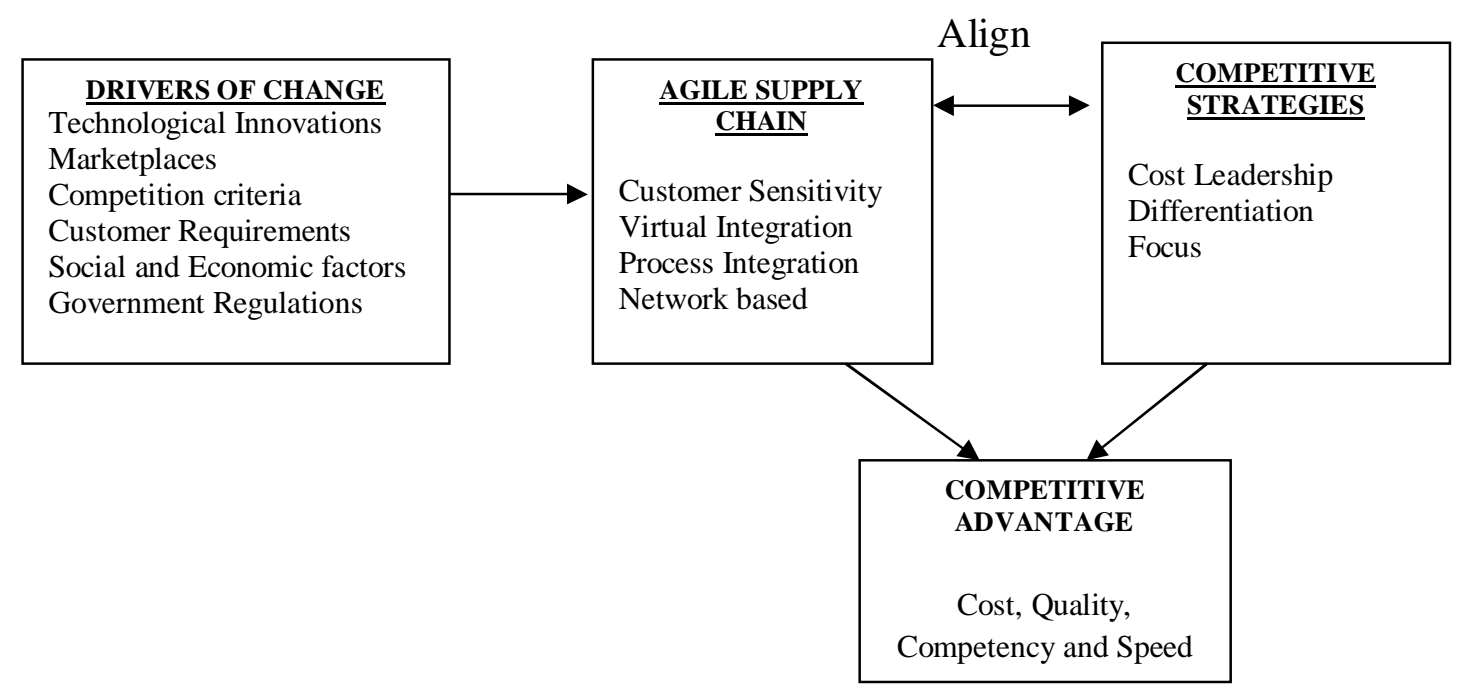

\section{CONCLUSION}

The main objective of the paper was to explore the concept of agile supply chain and to determine the link between agile supply chain and competitive advantage. Based on literature explored, because agile supply chain is a winning strategy for growth, and lean supply chain a pre-requisite for the creation of an agile supply chain, it is evident that it is a strategy for competitive advantage. Agile supply chain is triggered by"change"which is the only constant thing in the business environment. Furthermore, relevant literature has shown that business success can only be achieved through effective co-ordination of all the participants companies across the supply chain (Van Hoek et al, 2001) to shorten product life cycle and reduce product cost (Levary, 2000) as supply fluctuates more rapidly than ever before. Breaking through this challenge, it is necessary that organizations focus their effort upon achieving greater agility such that it can respond in shorter time frames both in terms of volume change and variety change (Christopher, 2005). Agility is considered as a vital factor for business success in complex industrial landscapes as it enables rival firms to efficiently perform under time-to-market pressures. Putting the idea of lean and agile supply chain together, it can be concluded that lean is needed to build agility and the pre-requisite for success in the market place is an agile supply chain. The key to the success of an organisation is to align agile supply chain strategy to the differentiation strategy to meet the overall objective for competitive performance, hence competitive advantage. Therefore, agile supply chain is a strategy for competitive advantage. If you're not agile, you can't do it, because customer expectations are never static.

Therefore, to sustain and maintain supply chain agility, an organisation should:

- Commit to flexibility and adaptability in regards to your supply chain. Convince those who will implement the necessary programs of its importance.

- Identify the factors involved in past problems with your company's supply chain. Review your business's past history for its biggest problems. 
- Implement simple solutions for these problems.

- Design programs for solutions that are not solved simply. Prioritize problems on the basis of which are most likely. Systematically move through these problems.

- Address flexibility and adaptability while moving through the later stages of disaster-proofing your production. Begin by asking for input from all levels of production, even levels below that of managers.

- $\quad$ Centralize responsibility for reviewing plans for change. Those with the responsibility should have a broad base of experience. Involve consulting firms if needed, but critically assess the skills of the consultants such that they fit into your team.

- Integrate the newer theories of agile supply chains, specifically those that allow for greater coordination between customers and suppliers, where appropriate. 


\section{REFERENCES}

Borade, A. B and Bansod, S.V (2007). "Domain of Supply Chain management-A State of Art". Journal of Technology Management and Innovation. 2:4.

Chopra, S and Meindl, P 2007. Supply chain management: Strategy, Planning and Operation. Upper saddle River, New Jessey: Pearson.

Christopher, M., (2005), "Logistics and Supply Chain Management- Creating Value-Adding Networks," Prentice Hall/ Financial Times.

Childerhouse, P., Disney, S. and Towill, D.R., (2000), "Speeding up the Progress Curve towards Effective Supply Chain Management", International Journal of Supply Chain Management', 5: 3, pp 176-186.

Christopher M., (1998), Logistics and Supply Chain Management - Strategies for Reducing Cost and Improving Service, Prentice-Hall.

Christopher, M., (2000), "The Agile Supply Chain: Competing in Volatile Markets", Ind. Mark. Man., 29:1, pp. 37-44.

Christopher, M. (2005), Logistics and supply chain management: Creating value-added networks. Harlow, England: Prentice Hall.

Christopher, M. and Towill, D.R., (2000), "Supply Chain Migration from Lean and Functional to Agile and Customised”, Int. Jnl. Sup. Ch. Man, 5:4, pp 206-213.

Christopher, M. and Towill, D.R. (2002), "Developing Market Specific Supply Chain Strategies", International Journal of Logistics Management, 13:1, pp. 1-14.

Christopher M, Peck, H and Towil, D. (2006), A Taxonomy for selecting global supply chain strategies, International Journal of Logistics Management, 17: 2, pp 277-287.

Fawcet, SE, Ellram, LM and Ogden, JA, (2007), Supply Chain Management: From Vision to Implementation. Upper Saddle River, New Jersey: Prentice hall.

Fisher, M., (1997), "What is the Right Supply Chain for your Product?", Harvard Business Review, March/April.

Gansler C, Luby RE Jr., Kornberg B (2004). ' Supply Chain Management in Government and Business', in Transforming Government in Gansler J, and Luby, JR. The IBM Centre for the Business for Government Series.

Goldman, S.L., Nagel, R.N. and Preiss, K., (1995), Agile competitors and virtual organisations: Strategies for enriching the customer. New York: Van Nostrand Reinhold.

Gurumurthy, A and Kodali R (2009), Application of benchmarking for assessing the lean manufacturing implementation. Benchmarking: An international journal. Vol. 16:2, pp. 274-308.

Handfield, RB, Monczka, RM, Giunipero, LC \& Patterson, JL. (2009), Sourcing and supply chain management. 4th edition. Ontario: South Western.

Harrison, A., Christopher, M and van Hoek, R., (1999), "Creating the agile supply chain", working paper, School of Management, Cranfield University.

Hill, T. (1993), Manufacturing Strategy: Text and Cases, Second Edition, MacMillan Press, London. 
Hugo, WMJ, J.A. Badenhorst-Weiss, and E.H.B. Van Biljon. (2004), Supply chain management: logistics in perspective. $3^{\text {rd }}$ edition, Pretoria: Van Schaik.

Klemencic, E. (2006), Management of Supply Chain-Case of Danfoss District Heating Business Area, Faculty of Economics, Ljubljana University, February 2006.

Kisperska-Moron, D and Swierczek, A. (2008), The agile capabilities of Polish companies in the supply chain: An empirical study. Int. J. Production Economics.

Ismail, HS and Sharifi, H. (2006), A balanced approach to building agile supply chains, International Journal of Physical Distribution and logistics Management, 26:6, pp.431-444.

Lambert, D.L. (2006). Supply Chain Management: Processes, Partnerships, performance, $2^{\text {nd }}$ edition, The Hartley Press, USA.

Leenders, M.R \& Fearon, H.E., (1997), Purchasing and supply chain management Chicago: Irwin, (11th ed).

Lee, W.B., Lau, H.C.W., (1999). Factory on demand: The shaping of an agile network. International Journal of Agile Manufacturing Systems 1:2, pp.83-87.

Mason-Jones R \& Towill DR (1999) Total cycle time compression and the agile supply chain. International Journal of Production Economics 62, pp. 61-73.

Mason-Jones, R., Naylor, J.B., and Towill, D. (2000), "Engineering the Leagile Supply Chain”, to be published, Int. Jnl. Agile Man. Systems.

McKinnon A (2001), In: Brewer AM, Button KJ \& Hensher DA (eds) Handbook of Logistics and Supply-Chain Management. Pergamon, pp.157-170.

Mentzer, J. T., Ed., (2001), Supply Chain Management. Thousand Oaks, Sage Publications', Inc.

Monczka, RM, Trent, RJ \& Handfield, RB. 2005, Purchasing and Supply Chain Management. 3rd ed. Cincinatti: South Western.

Naylor J.B., M. Naim. M. \& Berry D. (1999), Leagility: Integrating the lean and agile manufacturing paradigms in the total supply chain. Int. J. Production Economics, 62, pp.107 - 118.

Njoroge J (2009), Effects of the global financial crisis on corporate social responsibility in multinational companies in Kenya, Working paper, Covalence SA, Geneva, 26.06, 2009.

Pandey, V.C and Garg S (2009), Analysis of interaction among the anablers of agility in supply chain. Journal of advances in management research, 16:1, pp.99-114.

Porter, M. E. (1995), 'The Competitive Advantage of the Inner City', Harvard Business Review, May-June, 55-71.

Ross D.F., (1998), Competing Through Supply Chain Management. Creating Market-Winning Strategies through Supply.

Samaranayake P, 2005, A conceptual framework for supply chain management: a structural integration. Supply chain management: An international journal, 10:1, 47-59.

Sánchez, A., \& M. Pérez. 2005, Supply Chain Flexibility and Firm Performance: A Conceptual Model and Empirical Study in the Automotive Industry, International Journal of Operations \& Production Management, 25:7, 2005, pp. 681-700. 
Sherer S, 2005. From supply-chain management to value network advocacy: implications for esupply chains. Supply chain management: An international journal, 110:2 (2005), pp.77-83.

Simons D and Zokaei K (2005), Application of lean paradigm in red meat processing. British food journal, Vol. 107, No.4, 2005, pp.192-211.

Taj S and Berro L. (2006), Application of constrained management and lean manufacturing in developing best practices for productivity improvement in an auto-assembly plant, International Journal of Productivity and Performance Management, 55: 3/4, pp.332-345.

Van Hoek, R.I., Harrison, A., Christopher, M., (2001), Measuring agile capabilities in the supply chain. International Journal of Operations and Production Management 21:1/2, pp.126-147.

Vinodh, S., Sundararaj, G and Devadasan, SR (2009), Total agile design system model via literature exploration. Industrial management and data system, 109: 4, pp. 570-588. 